\title{
Urinary Kidney Injury Molecule-1 (KIM-1) in Early Diagnosis of Acute Kidney Injury in Pediatric Critically III
}

\author{
Irma Lestari Paramastuty ${ }^{1,3^{*}}$, Krisni Soebandiyah ${ }^{2,3}$, Basuki B. Purnomo ${ }^{2,3}$ \\ ${ }^{1}$ Department of Child Health, Faculty of Medicine, Brawijaya University, Malang, Indonesia \\ ${ }^{2}$ Department of Urology, Faculty of Medicine, Brawijaya University, Malang, Indonesia \\ ${ }^{3}$ dr. Saiful Anwar Public Hospital, Malang, Indonesia
}

\begin{abstract}
Acute kidney injury (AKI) often associated with a high hospital morbi-mortality rate in the intensive care unit patients. Kidney injury molecule-1 (KIM-1), has many characteristics of ideal biomarker for kidney injury. The aim of this study was to compared the temporal pattern of elevation urinary KIM-1 level following critically ill children with $\mathrm{SCr}$ as standart biomarker of AKI. Prospective analytic observational study was conducted during October to March 2014 in the Saiful Anwar General Hospital and Physiology Laboratory Brawijaya University. There were 13 critically ill as subjects. SCr and KIM-1 levels from all subjects were measured three times (at admission, after 1st and 6th hour). Subjects were devided into AKI - non-AKI groups by SCr level and survivor - non survivor group at the and of the observations. Results showed that there were significantly increased levels of KIM-1 in the AKI and non-AKI and survivor-non survivor group at time point. However, we found that delta KIM-1 at time point increased significant in non AKI group and survivor group. KIM-1 at admission can diagnosed AKI in critically ill children. We conclude that urinary KIM-1 is a sensitive non-invasive biomarker to diagnosed acute kidney injury in critically ill children. Increase level of KIM-1 by time shows protective and good outcome in critically ill children.
\end{abstract}

Keyword: AKI, Critically ill, children, non-invasive biomarker urinary KIM-1 level

\section{INTRODUCTION}

Acute kidney injury (AKI) is characterized by a sudden and generally reversible renal function impairment, involving inability to maintain the homeostasis, and may or not be accompanied by reduced diuresis. During the childhood, the etiology of AKI are sepsis, nephrotoxic drugs, and renal ischemia in criti-cally ill patients, particularly those staying in in $\rightarrow$ tensive care units (ICUs), are exposed to a number of conditions which may result in renal impairment, thus significantly increasing $40-90 \%$ the morbi-mortality rate. $\mathrm{Hy}-$ povolemia leading to hypoperfusion and consequent hypoxia; inflammatory and thrombotic events caused by sepsis; systemic inflammation from trauma, major surgeries, drugs interfering with the renal hemodynamics. Sepsis, and specially the septic shock, is one of the

\footnotetext{
${ }^{*}$ Corresponding author:

Irma Lestari Paramastuty

Faculty of Medicine, Brawijaya University

Jl. Veteran, Malang 65145, Indonesia

E-mail: irmcool@yahoo.com
}

main causes of AKI ntil now there were no data show pediatric AKI incidence in Indonesia. In Sanglah Hospital, Denpasar the incidence of pediatric AKI in pediatric intensive care unit (PICU) is $16.77 \%$ [2], while in PICU Wahidin Sudirohusodo Hospital, Makasar $80.05 \%$ critically ill patients had elevated of serum creatinine (SCr) level [3]. In 2012, the incidence of AKI in pediatric ward Saiful Anwar General Hospital is 4 cases per year and 1 cases per year in PICU [4]. At 3 to 5 -year follow-up, $40 \%$ to $50 \%$ of pediatric patients who had AKI show signs of chronic renal insufficiency, indicating that sublethal injury permanently alters the renal bed [5].

Serum creatinin (SCr) concentration is the surrogate test used to diagnose AKI but inadequate gold standard for several reasons. $\mathrm{SCr}$ has poor specificity in the settings of prerenal azotemia, changes in dietary intake, and drug-induced changes in tubular secretion of creatinine, all of which may lead to change in $\mathrm{SCr}$ without actual injury to the kidney, poor sensitivity in the setting of adequate renal reserve,when SCr may not 


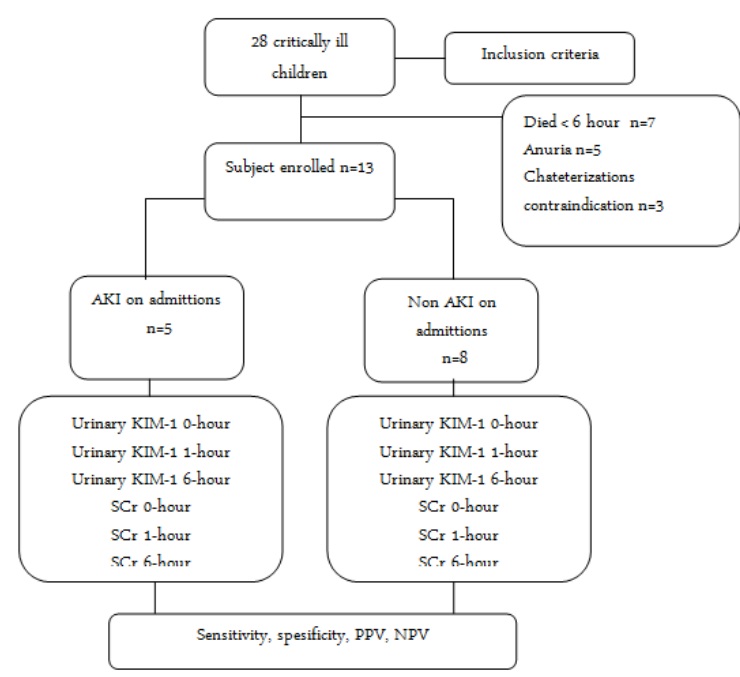

Figure 1. Flowchart of research subjects

change despite acute tubular injury because of compensatory increases in function by other nephrons. The use of SCr may also lead to delays in diagnosis because of the relatively slow kinetics of the rise in $\mathrm{SCr}$ after injury [6].

KIM-1 (also known as TIM-1-T-cell immunoglobulin and mucin-containing molecule) is a type I cell membrane glycoprotein containing in its extracellular portion a 6-cysteine immunoglobulin-like domain and a Thr/Ser-Pro rich domain characteristic of mucinlike Oglycosylated proteins. The KIM-1 gene or protein expression is undetectable in normal kidney, present in damaged tubular epithelial cells undergoing dedifferentiation and replication, persist until the damaged cells have completely recovered.

KIM-1 was a phosphatidylserine receptor that conferred on epithelial cells the properties of highly phagocytic cells, was able to specifically bind phosphatidylserine on the apoptotic cell surface and transform tubular epithelial cells into semiprofessional phagocytes, which enhanced the clearance of apoptotic and necrotic cell debris. Functionally, the ability of KIM-1 to phagocytose apoptotic and necrotic cells in the tubule of the kidney may be critical for remodeling after injury to cleared of dead cell debris to relieve intratubular obstruction. KIM-1 may play an important role in limiting the autoimmune response to injury because phagocytosis of apoptotic cells mediated by KIM1 may result in the generation of antiinflammatory cytokines and restrain the activation of proinflammatory cytokines [7].

Research on urinary KIM-1 in animals and humans has been done but has not been done before in critically ill children in Indonesia. The purpose of this study is to compare the level of urinary KIM- 1 with $\mathrm{SCr}$ as conventional AKI biomarker at time point in critically ill children.

\section{MATERIALS AND METHODS \\ Study design and subject}

The current prospective observational analytic study was used in critically ill children who was stay in PICU/HCU/ER Saiful Anwar General Hospital, between October 2013 and March 2014. A total of 15 out of 28 critically ill children whose parents signed written informed consent was selected as subjects. This study protocol was approved by research ethical clearance, issued by Health Research Ethics Commision, dr Saiful Anwar General Hospital, Malang Indonesia. The outcome was devided into 2 groups, AKI and non-AKI group on baseline examination then the changes of urinary KIM-1 and serum creatinine level was measured at the times point of admittions, 1 hour and 6 hour hospitalization.

\section{Inclusions criteria}

Critically ill children, aged 1-18 years, treated in the PICU/ ICU/ER, PaO2/FiO2 < $300 \mathrm{mmHg}$ or use mechanical ventilation, hemodynamic instability or requiring resuscitation or inotropic drugs, the parents willing to signed written informed consent to follow this research. Dropped out criteria are critically ill children whose met the inclusion criteria, died before 6 hour of admittions, or oligury during the time point of observations, or catheterization contraindication.

\section{Exclusions criteria}

Children with renal insufficiency (nephrotic syndrome, nephritic syndrome), patients who received hemodyalisis, congenital kidney disease, autoimmune disease related to kidney, renal malignancy.

\section{Operational definitions}

Acute kidney injury (AKI) is sudden and generally reversible renal function impairment, involving inability to maintain the homeostasis, and may or not be accompanied by reduced diuresis. AKI criteria in pediatric standardized using pediatric risk injury failure loss endstage (pRIFLE). Stage risk is characterized by reduction in estimated creatinine clearance $(\mathrm{eCCl}) \geq$ $25 \%$ or a decrease in urine output $0.5 \mathrm{~mL} / \mathrm{kg} / \mathrm{h}$ in 8 hours, stage injury is a reduction in estimated creatinine clearance $(\mathrm{eCCl}) \geq 50 \%$ or a decrease in urine output $0.5 \mathrm{~mL} / \mathrm{kg} / \mathrm{h}$ in 16 hours, stage failure is a reduction in estimated creatinine clearance $(\mathrm{eCCl}) \geq$ 
$75 \%$ or a decrease in urine output $0.3 \mathrm{~mL} / \mathrm{kg} / \mathrm{h}$ in 24 hours or anuria within 12 hours.Children with high risk $\mathrm{AKI}$ is critically ill children who are treated in an intensive care unit (PICU/HCU) or ER who had experienced hypoxia, shock, sepsis, trauma, major surgery, use of sedatives, vasopressors, radiological contrast nephrotoxic drugs that interfere with renal hemodynamics. Critical illness was defined as a disturbance of homeostasis that requires treatment in an intensive care unit or require mechanical ventilation or $\mathrm{PaO} 2 / \mathrm{FiO} 2<300 \mathrm{mmHg}$, requiring intravenous inotropic drugs or intravenous vasoconstrictive agents. Disease severity defined by a score of pediatric logistic organ dysfunction (PELOD score), patient stratification scale is divided into 3 scale, low scale ( $<10$ points), medium scale (10-19 points), and high scale $(>20$ points) with the highest point is 71 .

\section{Processing and storage of urinary samples}

Urinary collections was taken with aseptic method through the catheter in conjuction with serum sampling at three time point (on admittion, 1-hour, and 6-hour of admittions). Urinary samples then centrifuged to seperate the particles of urine and stored at $-20^{\circ} \mathrm{C}$. Avoid the repeated freezing and thawing cycles.

\section{Measurement of serum creatinine (SCr) level}

Serum creatinine level was measured at the Laboratory of Pathology Clinic, Saiful Anwar General Hospital using enzymatic methode, Cobaz 6000.

\section{Measurement of urinary KIM-1 level}

Measurement of levels of urinary KIM-1 was conducted at the Laboratory of Physiology UB using the Human TIM-1/KIM-1 / HAVCR immunoassay for the quantitative determination of human T-cell immunoglobulin mucin (TIM-1) concentrations in urine, made by Quantikine ELISA (R \& D system), catalog number DKM-100. This assay employs the quantitative sandwich enzymeimmunoassay technique. A monoclonal antibody specific for TM-1 has been precoated onto a microplate. Standarts and samples are pipetted into the wells and any TIM-1 present is bound by the immobilized antibody. After washing away any unbound substances, an enzyme-linked polyclonal antibody specific for TIM-1 is added to the wells. Following a wash to remove any unbound antibodyenzyme reagent, a substrate solution is added to the wells and color development is stopped and the intensity of the color is measured.
Table 1. Characteristics of subjects based on AKI and non AKI group in pediatric critically ill

\begin{tabular}{|c|c|c|c|c|}
\hline \multirow{2}{*}{ Characteristic } & \multirow[t]{2}{*}{$n(\%)$} & \multicolumn{2}{|c|}{ Outcome } & \multirow{2}{*}{$p$} \\
\hline & & $A K I$ & Non $A K I$ & \\
\hline Total subject & 13 & & & \\
\hline Sex & & & & $0.086^{\mathrm{C}}$ \\
\hline Boys & $6(46)$ & 4 & 2 & \\
\hline Girls & $7(54)$ & 1 & 6 & \\
\hline \multicolumn{5}{|l|}{ Age (months) } \\
\hline Average & & 58.40 & 62.62 & $0.085^{\mathrm{a}}$ \\
\hline Standart Deviations & & \pm 45.64 & \pm 52.66 & \\
\hline $1-5$ years & $8(61.5)$ & & & \\
\hline $6-10$ years & $4(30.8)$ & & & \\
\hline $11-15$ years & $1(7.7)$ & & & \\
\hline \multicolumn{5}{|l|}{ BMI (kg/m2) } \\
\hline Average & & 15.32 & 15.51 & $0.086^{\mathrm{a}}$ \\
\hline Standart Deviations & & \pm 2.10 & \pm 2.51 & \\
\hline \multicolumn{5}{|l|}{ Nutritional status } \\
\hline Malnourished & $2(15.4)$ & & & \\
\hline Underweight & $5(38.5)$ & & & \\
\hline Normal weight & $4(30.8)$ & & & \\
\hline Overweight & $2(15.4)$ & & & \\
\hline \multicolumn{5}{|l|}{ Lenght of stay } \\
\hline Average & & 17.80 & 15.50 & $0.647^{\mathrm{a}}$ \\
\hline Standart Deviations & & \pm 10.96 & \pm 6.82 & \\
\hline \multicolumn{5}{|l|}{ Admission in } \\
\hline ER & $1(7.7)$ & & & \\
\hline $\mathrm{HCU}$ & $8(61.5)$ & & & \\
\hline PICU & $4(30.8)$ & & & \\
\hline PELOD score & & & & $0.028^{\mathrm{a}^{*}}$ \\
\hline Average & & 4.34 & 2.08 & \\
\hline Standart Deviations & & \pm 1.85 & \pm 1.38 & \\
\hline Low risk & $6(46.2)$ & & & \\
\hline Moderate risk & $4(30.8)$ & & & \\
\hline High risk & $3(23.1)$ & & & \\
\hline Predicted death rate $(\%)$ & & & & $0.031^{b^{*}}$ \\
\hline Average & & 50.74 & 0.70 & \\
\hline Outcome & & & & $0.044^{c^{*}}$ \\
\hline Survivor & $5(38)$ & 0 & 5 & \\
\hline Non survivor & $8(62)$ & 5 & 3 & \\
\hline \multicolumn{5}{|l|}{ Serum creatinine } \\
\hline \multicolumn{5}{|l|}{$(\mathrm{mg} / \mathrm{dL})$} \\
\hline Average 0 hour & & 0.49 & 0.45 & $0.794^{\mathrm{a}}$ \\
\hline Average 1 hour & & 0.60 & 0.37 & $0.213^{\mathrm{b}}$ \\
\hline Average 6 hour & & 0.72 & 0.32 & $0.020^{\mathrm{a}^{*}}$ \\
\hline \multicolumn{5}{|l|}{ Urinary KIM-1 (mg/dL) } \\
\hline Average 0 hour & & 3.96 & 1.58 & $0.059^{\mathrm{a}}$ \\
\hline Average 1 hour & & 4.61 & 2.07 & $0.141^{\mathrm{a}}$ \\
\hline Average 6 hour & & 3.58 & 2.23 & $0.306^{\mathrm{b}}$ \\
\hline
\end{tabular}

a) Independent t-test; b) Mann-Whitney test; c) Chi-square; *) Significant $\mathrm{p}<0.05$ 


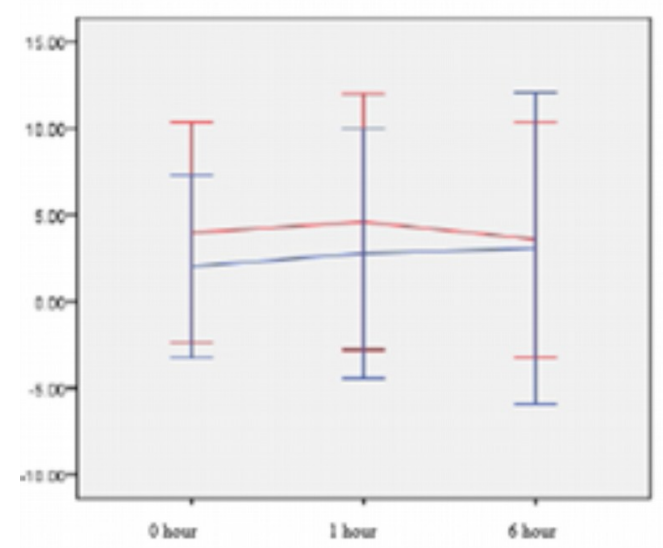

(a)

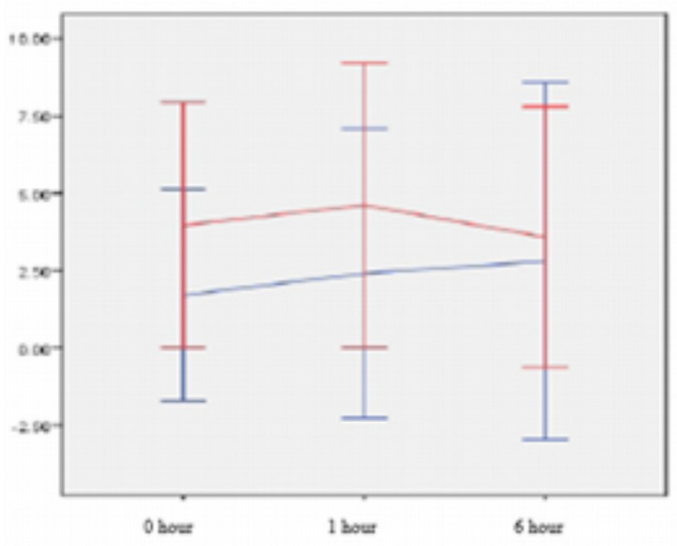

(c)

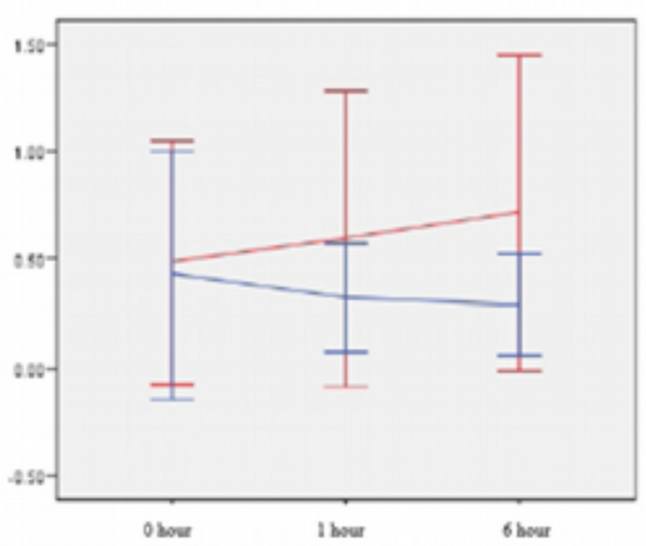

(b)

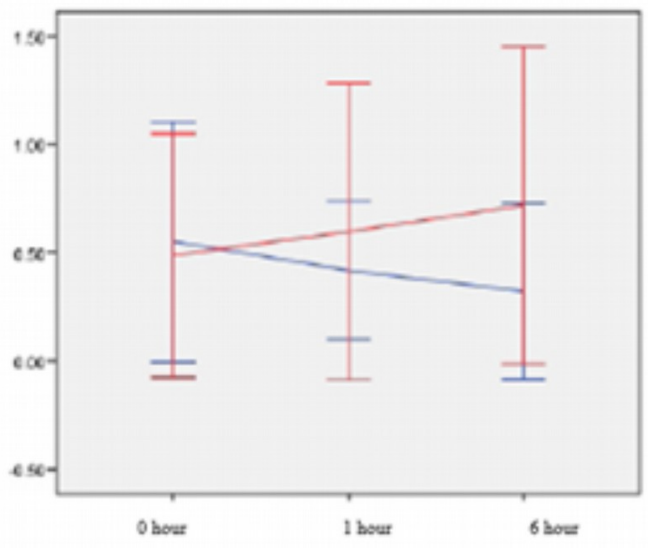

(d)

Figure 2. The level of urinary KIM-1 and serum creatinine at time point. (a) Urinary KIM-1 level between AKI and non AKI group and (b) Serum creatinine between AKI and nonAKI group; (c) Urinary KIM-1 level between survivor and non survivor and (d) Serum creatinine level between survivor and non survivor group

\section{Statistical analysis}

The differences KIM-1 level and serum creatinine at time point between AKI and non AKI group or survivor and non survivor were analyzed using independent t-test, then analyzed receiver operating characteristic (ROC) was performed to predict the presence of early AKI in critically ill children. The statistic analysis used a statistical package for the social sciences (SPSS 15.0) for Windows.

\section{RESULTS AND DISCUSSION}

Table 1 shows subjects's characteristics based on gender, age, BMI, lenght of stay, the mean of serum creatinine levels and urinary KIM-1 level between AKI and nonAKI group. Only PELOD scores, predicted death rate, outcome show significant $(\mathrm{p}<0.05)$. Lenght of stay of AKI group in pediatric critically ill is 17 days while nonAKI is 15 days. Score PELOD is one of MODS score in pediatric critically child that associated with increased mortality. 8 Research conducted by Leteurtre et al. (2010) state that the first day of PELOD scores associated with significant prognostic factor (odds ratio 1.16 that increase in every point, 95\% CI) and the score 10-20 PELOD increase mortality of pediatric critically ill patients in the PICU.9

Refer to Figure 2A. found no significant difference in the urinary KIM - 1 level and between AKI and non AKI groups at time point (independent $\mathrm{t}$-test $\mathrm{p}>$ 0.05 ), at admission, 1 hour and 6 hour respectively $\mathrm{p}=0.059, \mathrm{p}=0.141,0=0.306$. Using pairwaise comparison to measured delta urinary KIM-1 level between time point we found significan between 0 to 1 hour $(\mathrm{p}=0.011)$. 
Table 2. Area under curve ROC urinary KIM-1 and serum creatinine

\begin{tabular}{ccc}
\hline Variable & Area Under Curve (95\% CI) & $\mathrm{p}$ \\
\hline KIM-1 0 hour & $0.850(95 \% \mathrm{CI}=0.630$ to 1.070$)$ & $0.040^{*}$ \\
KIM-1 1 hour & $0.700(95 \% \mathrm{CI}=0.392$ to 1.008$)$ & 0.242 \\
KIM-1 6 hour & $0.675(95 \% \mathrm{CI}=0.345$ to 1.005$)$ & 0.306 \\
Serum creatinine 0 & $0.575(95 \% \mathrm{CI}=0.246$ to 0.904$)$ & 0.661 \\
hour & & \\
Serum creatinine 1 & $0.712(95 \% \mathrm{CI}=0.426$ to 0.999$)$ & 0.213 \\
hour & & \\
Serum creatinine 6 & $0.900(95 \% \mathrm{CI}=0.727$ to 1.073$)$ & $0.019^{*}$ \\
hour & & \\
\hline$\left.{ }^{*}\right) \mathrm{p}<0.05$ significant & &
\end{tabular}

Refer to Figure $2 \mathrm{C}$ at the 0 hour or the initial observation there were no difference between urinary KIM-1 levels in survivor and non survivor as well as 1 and 6 hour admission (Mann-Whitney $U$ test respectively $\mathrm{p}=0.057, \mathrm{p}=0.188$, and $\mathrm{p}=0.242$ ). Using Wilcoxon test (post hoc Friedman) we found significantly increased delta urinary KIM-1 level between 0-1 hour and 0-6 hour in survivor group respectively $\mathrm{p}=0.043$ and $\mathrm{p}=0.043$.

Refer to Figure $2 \mathrm{~B}$ serum creatinine levels measured at the 0,1 , and 6 hour after admissions. There were no significant different between 0 and 1 hour admission between AKI and non AKI group but at 6 hour it show significant different (independent t-test $\mathrm{p}=0.020$ ) while Figure $2 \mathrm{D}$ showed that there were no significant different serum creatinin level between survivor and non survivor at time point (independent $\mathrm{t}$ test respectively $\mathrm{p}=0.347, \mathrm{p}=0.608$, and $\mathrm{p}=0.178)$.

Kidney injury molecule- 1 (KIM-1) is a transmembrane protein in humans that are not detected in urine of subject's normal kidney tissue in normal conditions but expressed in very high levels in proximal tubular epithelial cells undergo dedifferentiation [10]. In this study urinary KIM-1 level found no significant difference at time point between AKI and non AKI groups. This study is similar to research conducted by Boghdady et al. (2013) in adult critically ill patients that the levels of urinary KIM-1 level at admissions the ICU did not differ significantly in AKI and non AKI group but that study found significant differences in the $6-$ 12 hour of admissions [11]. Other research states that the expression of KIM-1 is slower than the urine NGAL in patients after cardiac surgery. This can be explained by the presence of subclinical injury that occurred outside of the renal proximal tubule or even severe damage of proximal tubular epithelial cells becau-

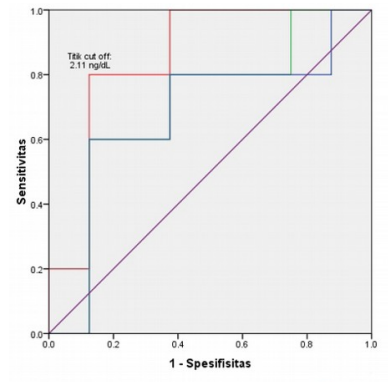

(a)

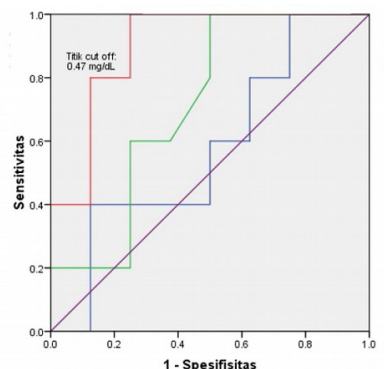

(b)
Figure 3. Urinary KIM-1 (a) and serum creatinine ROC (b)

se of KIM-1 is a transmembrane glycoprotein is confined only to the surviving proximal tubular epithelial cells after the injury [12].

In this study found no significant difference in the levels of urinary KIM-1 between survivor and non survivor in time point but it was found a significant difference in the levels of urinary KIM-1 0-1 hours and 0-6 hours admissions in survivor. The trends tendency found that the levels of urinary KIM-1 non survivor is higher than survivor. Research conducted by Han et al.. (2002) stated that urinary KIM-1 was significantly increased in patients ischemic ATN 12 hours after ischemic injury [13]. High urinary KIM-1 expression is associated with poor clinical outcome in AKI patients $[11,14]$. Research conducted by Van Timmeren et al. (2007) stated that the levels of urinary KIM-1 related to the degree of renal tubular damage histopathology [15]. While the tendency found that the levels of survivor urinary KIM-1 continues to increase until hours to 6 treatments. Research conducted by Ichimura et al.. (2008) stated that the KIM-1 mediates clearance of apoptotic and necrotic debris in the tubular lumen and triggers apoptosis mediated internalization when binding to the cell surface. Phagocytosis of apoptotic cells led to an increase of anti-inflammatory cytokines that resist the activation of proinflammatory cytokines, as well as hepatocyte growth factor (HGF), known as renal repair factor, increased in epithelial cells phagocytize apoptotic cells [16]. Urinary KIM-1 increased along with the increase in bromodeoxyuridine (proliferation marker) and elastin (dedifferentiation marker) so that the KIM- 1 plays a role in the regeneration of tubular epithelial cells [7]. So that researchers can only speculate that urinary KIM-1 has a detrimental effect in a harmful and protective mechanism [15]. Increased levels of urinary KIM-1 related to the degree of renal tubular damage associated with death, but on the other side of the KIM-1 urinalysis provide a protective effect by inducing apoptosis and anti-inflammatory cy- 
tokines.

In this study there were significant differences in serum creatinine levels between patients between AKI and non AKI group at 6 hour admissons. However, there no significant differences at time point between survivor and non survivor. In other hand the tendency of serum creatinine levels in non survivor increased at time point while decreased in survivor. Research conducted by Newsome et al. (2008) suggest that small changes in serum creatinine levels during treatment increases the risk of terminal renal failure and death. 17 Increased of serum creatinine $0.3 \mathrm{mg} / \mathrm{dL}$ or more associated with poor clinical outcome.18 A similar study is showed by Nin et al. (2009) who examined the serum creatinine levels in patients undergo mechanical ventilation that small changes of serum creatinine in the admissions while many clinicians do not react with changes of $0.3 \mathrm{mg} / \mathrm{dL}$ were associated with poor outcome. From this study it was found that delta serum creatinine of more than $0.31 \mathrm{mg} / \mathrm{dL}$ increase of 1.37 times the risk of death in patients with mechanical ventilation (95\% CI) [19].

Table 2 shows that AUC of urinary KIM-1 at admission 0.850 (>0.7) with a $\mathrm{p}$ value of 0.040 , so it can be used to predict the AKI in pediatric critically ill. Meanwhile, the levels of KIM-1 AUC at 1 hour and 6 hour is $0.700(p=0.242)$ and $0.675(p=0.306)$ so it can not be used as a predictive AKI. The AUC of creatinine levels at 6 hour is $0.900(>0.7)$ with $p=0.019$, which means creatinine levels to- 6 hours can be used as a predictor AKI.

Figure $3 \mathrm{~A}$ shows the ROC curve levels of KIM-1 hour 0 is 0.850 ( $95 \% \mathrm{CI}=0.630$ to 1.070$), \mathrm{p}=0.040$. Based on the ROC curve can be determined cut-off value for AKI classification. ROC curve analysis of the urine levels of KIM-1 0 hour is $2.11 \mathrm{ng} / \mathrm{dL}$ (Table 3). AUC of creatinine 6 hour (red line on Figure $3 \mathrm{~b}$ ) is $0.900(95 \% \mathrm{CI}=0.727$ to 1.073$) \mathrm{p}=0.019$. From the ROC curve analysis of 6 hour creatinine levels, note that the cut-off point for predicting creatinine levels AKI output is $0.465 \mathrm{mg} / \mathrm{dL}$.

Table 3. Cut off of urinary KIM-1 at admission

\begin{tabular}{ccc}
\hline Variable & \multicolumn{2}{c}{ Outcome } \\
& AKI & Non AKI \\
\hline Urinary KIM-1 at 0 hour & & \\
$\geq 2.11 \mathrm{ng} / \mathrm{dL}$ & $4(31 \%)$ & $1(8 \%)$ \\
$<2.11 \mathrm{ng} / \mathrm{dL}$ & $1(8 \%)$ & $7(54 \%)$ \\
\hline
\end{tabular}

This is in line with research by Prozialeck et al.
(2009) which states that the increased of urinary KIM1 earlier than the increase in serum creatinine [20]. Research conducted by Han et al. (2002) in critically ill adult patients showed that the ranges of urinary KIM-1 levels were $1.34 \mathrm{ng} / \mathrm{dL}$ to $2.99 \mathrm{ng} / \mathrm{dL}$ [13]. In a study conducted by Han et al. (2008) in patients whose done cardio pulmonary baypass found increased of urinary KIM-1 level at 6-12 hours after surgery and urinary KIM-1 AUC at 2 hour admissions was 0.57 , while 12 and 24 hour was respectively 0.83 and 0.78 [21]. Research conducted by Liangos et al. (2009) states that between 6 urinary biomarkers studied in cardiac surgery patients, urinary KIM-1 has a good performance to predict AKI 2 hours after surgery with AUC 0.78 [22].

There are several limitation of the current result. The subject follow the study is relative small so the future study need a large number of pediatric critically ill in multicenter research. The increased levels of urinary KIM-1 significantly at 6-12 hours after renal injury need longer examination of serial urinary levels of KIM-1.
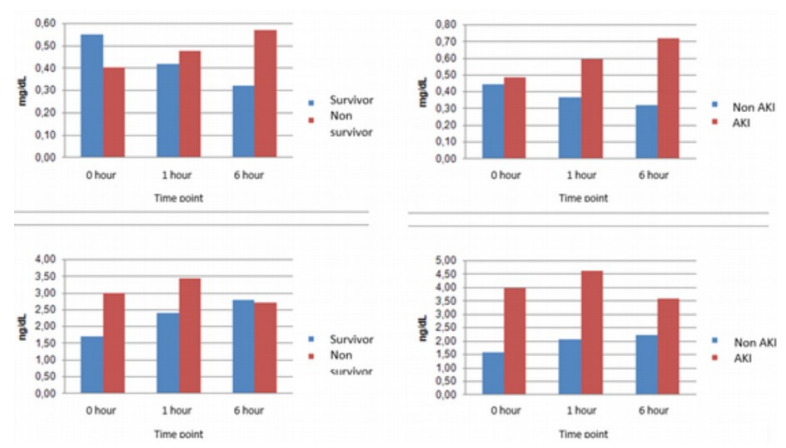

Figure 4. Urinary KIM-1 and serum creatinine level at time point

\section{CONCLUSIONS}

Our study state that urinary KIM-1 is a sensitive non-invasive biomarker to diagnose AKI in critically ill children. Increase level of KIM-1 by time shows AKI protective and good outcome. Urinary KIM-1 has good sensitivity and spesifisity to early diagnose AKI in critically ill children.

\section{ACKNOWLEDGMENT}

The author thanks to technician in Laboratory of Physiology Faculty of Medicine University of Brawijaya, Malang Indonesia (Mr. Satuman) for his good assistance. 


\section{REFERENCES}

1. KMS Freire, NL Bresolin, ACF Farah, FLC Carvahlo, JEC Goes (2010) Acute kidney injury in children: incidence and prognostic factors in critically ill patients. Rev. Bras. Ter. Intensiva. 22(2):166-174

2. GAP Nilawati (2012) Kejadian acute kidney injury dengan kriteria pRIFLE pada unit perawatan intensif anak rumah sakit Sanglah Denspasar. Sari Pediatri. 14(3): 158-161

3. H Albar (2013) Acute kidney injury in critically ill children at pediatric intensive care unit. CDK-211. 40(12): 890-893

4. Cahyono HA (2012) Laporan tahunan ruang rawat inap IV. In: RSSA I.K.A (ed). Malang: Instalasi rawat inap IV

5. RK Basu, P Devarajan, H Wong, SD Wheeler (2011) An update and review of acute kidney injury in pediatrics. Pediatr. Crit. Care. Med. 12(3):339-347

6. SS Waikar, RA Betensky, SC Emerson, JV Bonventre (2012) Imperfect gold standart for kidney injury biomarker evaluation. J. Am. Nephrol. 23:13-21

7. W Huo, K Zhang, Z Nie, Q Li, F Jin (2010) Kidney injury molecule-1 (KIM-1): a novel kidney- specific injury molecule playing potential double-edged functions in kidney injury. Transplatation Reviews. 24: 143-146

8. J Lacroix, J Cotting (2005) Severity of illness and organ dysfunction scoring in children. Pediatr. Crit. Care. Med. 6:S126-S134

9. S Leteurtre, A Duhamel, B Grandbastien, F Proulx, J Cotting, R Gottesman, A Joffe, B Wagner, P Hubert, A Martinot, J Lacroix, F Leclerc.(2010.) Daily estimation of the severity of multiple organ dysfunction syndrome in critically ill children. CMAJ. 182(11):1181-1187

10. Z Zhang, BD Humphreys, JV Bonventre (2007) Shedding of the urinary biomarker kidney injury molecule-1 (KIM1) is regulated by MAP kinases and juxtamembrane region. J. Am. Soc. Nephrol. 18:2704-2714

11. IMB Boghdady, MMEL Naggar, MM Emara, RM Elshazly, KS Mahmoud (2013) Kdney injury molecule-1 as an early marker for acute kidney injury in critically ill patients. Menoufia Medical Journal. 26: 98-104

12. HRH De Geus, G Fortrie, MGH Betjes, RHN van Schaik. ABJ Groenevelt (2013) Time of injury affects urinary biomarker predictive values for acute kidney injury in critically ill, non-septic patients. BMC Nephrology.14: 273

13. WK Han, V Bailly, R Abichandani, R Thadani, JV
Bonventre (2002) Kidney injury molecule-1 (KIM-1): a novel biomarker for human renal proximal tubule injury. Kidney Int. 62: 237-244

14. O Liangos, MC Perianayagam, VS Vaidya, WK Han, R Wald, H Tighiouart, RW MacKinnon, L Li, VS Balakrishnan, BJG Pereira, JV Bonventre, BL Jaber (2007) Urinary N-Acetyl- $\beta$-(D)-Glucosaminidase activity and kidney injury molecule-1 level are associated with adverse outcomes in acute renal failure. J. Am. Soc. Nephrol. 18: 904-912

15. MM Van Timmeren, MC Van Den Heuvel, V Bailly, SJ Bakker, H Van Goor, CA Stageman, (2007) Tubular kidney injury molecule-1 (KIM-1) in human renal disease. J. Pathol. 212: 209-211

16. T Ichimura, EJ Asseldonk, BD Humphreys, L Gunaratman, JS Duffield, JV Bonventre (2008) Kidney injury molecule-1 is a phosphatidylserine receptor that confers a phagocytic phenotype on epithelial cells. J. Clin. Invest. 118: 1657-1668

17. BB Newsome, DG Warnock, WM McClellan, CA Herzog, CI Kiefe, PW Eggers (2008) Long-term risk of mortality and end-stage renal disease among the elderly after small increases in serum creatinine level during hospitalization for acute myocardial infarction. Arc. Intern. Med. 168(6): 609-616

18. RL Mehta, J Kellum, S Shah S (2007) Acute Kidney Injury Network: report of an initiative to improve outcomes in acute kidney injury. Crit. Care.11(2): R31

19. $\mathrm{N}$ Nin, R Lombardi, F Fritos-Vivar, A Esterban, JA Lorente, ND Ferguson (2010) Early and small changes in serum creatinine concentrations are associated with mortality in mechanically ventilated patients. Shock. 34(2):109-116

20. WC Prozialeck, JR Edwardsa, PC Lamara, J Liub, VS Vaidya, JV Bonventre (2009). Expression of kidney injury molecule-1 (Kim-1) in relation to necrosis and apoptosis during the early stages of $\mathrm{Cd}$-induced proximal tubule injury. Toxicol. Appl. Pharmacol. 238(3):306-314

21. WK Han, SS Waikar, A Johnson A (2008) Urinary biomarkers in the early diagnosis of acute kidney injury. Kidney international. 73: 863-869

22. O Liangos, A Kolyada, H Tighiouart, MC Perianayagam, R Wald, BL Jaber (2009) Interleukin-8 and acute kidney injury following cardiopulmonary bypass: a prospective cohort study. Nephron. Clin. Pract. 113(3): c148-c154. 